\title{
A vertical ground reaction force-measuring treadmill for the analysis of prosthetic limbs
}

\author{
Léia Bernardi Bagesteiro*, David Gould, David John Ewins
}

\begin{abstract}
This paper presents the development of an instrumented-treadmill, designed for use in the evaluation of prosthetic limbs during amputee running. The motorised treadmill was chosen for this study because of its advantages over conventional ground mounted force platforms, e.g. decreased time required for the datacollection, laboratory space required, repeatability, control of speed, and improved statistical power through collection of a high number of successive foot contacts. The long-term aim of this work is to investigate amputee running and thus identify prosthetic limb/wearer characteristics, which may improve the training process and subsequent running experience. An existing treadmill was modified to measure the ground reaction force underneath the belt. A new treadmill bed was designed using finite element analysis techniques. Four biaxial strain gauge transducers were designed and fabricated in-house to measure the applied loads. The instrumented-treadmill has been statically and dynamically tested and calibrated, showing a maximum error of $\pm 3 \%$ and crosstalk of $\pm 4 \%$ to the horizontal force components, a hysteresis up to $8 \mathrm{~N}$, and a $250 \mathrm{~Hz}$ natural frequency. Associated software has been developed to capture, process and display information related to gait data in a format suitable for left and right limb comparison. A pilot study was conducted to examine the force-measuring treadmill for evaluating amputee running.
\end{abstract}

Keywords Gait analysis, Treadmill, Lower-extremity amputee, Prosthesis.

\section{Esteira instrumentada para medição da força de reação vertical do solo para análise de membros com próteses}

Resumo Este artigo apresenta o desenvolvimento de uma esteira instrumentada projetada para utilização na avaliação de membros com prótese durante a corrida de indivíduos amputados. A esteira motorizada foi escolhida para este estudo devido as suas vantagens com relação às convencionais plataformas de força, e.g. diminuição do tempo de coleta de dados, espaço requerido para o laboratório, repetibilidade, velocidade constante e melhora da força estatística devido à aquisição de grande número de contatos sucessivos. A longo termo, o objetivo deste trabalho é investigar a corrida de individuos amputados e, portanto, identificar caracteristicas membro/usuário da prótese, o que poderá melhorar o processo de treinamento e subsequentemente a experiência da corrida. Uma esteira existente foi modificada a fim de medir a força de reação do solo embaixo da cinta. Uma nova base para a esteira foi projetada usando técnicas de elementos finitos. Quatro transdutores biaxiais de força com extensômetros de resistência elétrica foram projetados e fabricados para medir as forças aplicadas. A esteira instrumentada foi calibrada e testada estática e dinamicamente, mostrando um erro máximo de $\pm 3 \%$ com um crosstalk de $\pm 4 \%$ nas forças horizontais, uma histerese até $8 \mathrm{~N}$, e uma frequência natural de $250 \mathrm{~Hz}$. Programas computacionais especificos foram desenvolvidos para capturar, processar e visualizar a informação relativa aos dados da marcha num formato apropriado para comparações entre membros esquerdo e direito. Um estudo piloto foi desenvolvido a fim de testar a esteira instrumentada na avaliação da corrida de amputados.

Palavras-chave Análise de marcha, Esteira, Amputado abaixo do joelho, Prótese. 


\section{Introduction}

More and more amputees are taking part regularly in strenuous recreational or competitive sports, in which running is often an important activity, as it is one of the fundamental motor patterns required in many games and sports. In parallel there has been growing interest in the need for sports oriented prosthetic limbs, demonstrated by studies of the recreational activities of lower extremity amputees (Dingwell et al., 1994; Enoka et al., 1982; Kegel et al., 1980; Pandian and Kowalske, 1999). Running was indicated as one of the most difficult activities to achieve and which caused the most discomfort. The combination of surgical skills, prosthetic procedures and therapy/ training programmes may lead to a situation in which amputees are able to successfully compete in sports because of their prostheses, rather than in spite of them (Michael et al., 1990). However, there continues to be a need to investigate the combination of prosthetic components for the amputee who wishes to participate in recreational sport (Ward and Meyers, 1995).

The alignment of amputee limbs for optimal running performance is often undertaken in a subjective manner by trained prosthetists. It is suggested that more formal, quantitative, gait analyses would be of substantial benefit in this process. However, there are difficulties associated with the standard gait analysis techniques that require subjects to perform multiple trials walking/running overground (OVGR) and placing their feet on one or more force plates. The data collection effort can be costly and time consuming and thus unsuitable for providing rapid feedback to patients in a rehabilitation setting.

A treadmill based force plate system would offer more rapid collection and comparison of temporal and kinetic parameters of gait for multiple successive strides, at a constant known speed, without forcing subjects to target their footsteps. In addition it would simplify the recording of metabolic, electromyography (EMG) and kinematic data. Nevertheless it also presents some difficulties including: acceptable measurement of the shear forces, fluctuations in belt speed and reproducing the environmental effects (e.g. visual information and air resistance).

The literature indicates conflicting opinion about the validity of the assumption that treadmill locomotion is similar to OVGR environment, and yet most of the studies considering running have focused on non-amputee subjects. From a theoretical approach (van Ingen Schenau, 1980), the mechanics of treadmill and OVGR running are basically the same as long as the belt speed is constant and with respect to a fixed coordinate system. In a review of biomechanics of running (Cavanagh, 1990; Kobylarz,
1990; Nigg et al., 1995), it was concluded that when significant differences were reported, they have generally been for speeds greater that $5 \mathrm{~m} / \mathrm{s}$. Not surprisingly the most common observation was that individuals required several training or practice sessions to become familiar and comfortable with treadmill ambulation and running.

Previous force-measuring treadmill devices (Belli et al., 1995; Davis and Cavanagh, 1993; Dingwell and Davis, 1996; Fewster and Smith, 1995; Fuglewicz and Klavoon, 1994) have been shown to reduce substantially the data-collection time for locomotion experiments, to allow for feedback to subjects and/or patients, and to enable experiments to be conducted that are not otherwise possible, e.g. real-time gait symmetry evaluation in non-amputee and amputee subjects and mechanics of running under simulated low gravity.

Ground reaction force measurements combining treadmill devices and force plates or force transducers have been built for individual research projects, with various degrees of success and cost. Kram and Powell (1989) mounted a commercial force platform directly underneath the treadmill belt, requiring a whole new treadmill apparatus to be built from conveyor belt parts. Others have tried using existing treadmills placing them on force measurement devices (Davis and Cavanagh, 1993; Dingwell and Davis, 1996; Johnson et al., 1993; Mainka and Boenick, 1993; Martin et al., 1987; Ohmichi, 1991). Additionally, different treadmill systems and dedicated software are commercially available (Belli et al., 1995; Fuglewicz and Klavoon, 1994).

The purpose of this study was to investigate amputee running, aiming to show the applicability of an instrumented-treadmill for the evaluation of different prosthetic limbs, through the measurement of running events, and subsequently a more extensive study. The designed treadmill will allow collection and processing of important parameters of gait symmetry during amputee running events, which will facilitate the analysis of specific mechanisms and different alignments on the amputee gait pattern. This paper describes the development of the instrumented treadmill and its preliminary evaluation for the analysis of adult treadmill running.

\section{Materials and Methods}

\section{Equipment specification}

Prior work on amputee running (Dingwell et al., 1994; Schneider et al., 1993; Winter and Sienko, 1988) have suggested that the most significant measurement for assessing prosthetic limb during amputee running focus 
around the vertical ground reaction force (VGRF) profile (i.e. peaks and curve shape); comparison between prosthetic and contralateral limb, best represented by symmetry indices (e.g. first VGRF peak, second VGRF peak, and stance time); and stride time and stride length. Consequently equipment that measures GRF and calculates derived running parameters during amputee running was considered necessary for this work. Since the variables to be measured are velocity sensitive and results need to be compared for different prosthetic limb settings, it was also necessary to be able to control the running velocity.

To facilitate comparisons between individuals with different body mass, body weight units (BW) are used for normalisation purposes. The VGRF running pattern for normal subjects is characterised by an initial high-frequency force peak (1.5-2.5 BW) that is followed by a second larger $(2.0-3.0 \mathrm{BW})$ but lower-frequency force peak. The horizontal GRF can generate an antero-posterior (AP) force peak of $0.5 \mathrm{BW}$; and a medio-lateral (ML) force peak of 0.35 BW (Cavanagh, 1990). Given a body weight of $1.0 \mathrm{kN}$, these figures indicated a measuring range of up to $3 \mathrm{kN}$ for the vertical direction and a maximum of $\pm 0.5 \mathrm{kN}$ for the horizontal directions, measured with an accuracy of $\pm 3 \%$. The accuracy requirements were based on previous studies by Bates et al. (1983) and Giakas and Baltzopoulos (1997), which have shown an intra-subject variability of up to $\pm 5 \%$ among GRF foot-strikes. Although not required for the work, it was agreed that the measurement of horizontal forces would be investigated in order to expand the gait information available from the equipment. The error in force application point (CoP - AP and ML) was specified to be no greater than $\pm 3.5 \%$. Assuming an average stride length of $2.1 \mathrm{~m}$ (running at $3.3 \mathrm{~m} / \mathrm{s}$ ), this would give an error of about $74 \mathrm{~mm}$, considered acceptable for running studies where stride length variability can be up to $\pm 5.8 \%$ (Cavanagh, 1990).

Distance running speeds may be said to range from $2.5 \mathrm{~m} / \mathrm{s}$ to $6 \mathrm{~m} / \mathrm{s}$, however this work has focused on velocities up to $3.3 \mathrm{~m} / \mathrm{s}$, measured with an accuracy of $\pm 2.5 \%$. This selection was made because most recreational runners run up to this speed (Cavanagh, 1990; Enoka et al., 1982). The stride length can be calculated from stride time and speed. Assuming less than $\pm 1 \%$ error in the time measurement and $\pm 2.5 \%$ from the speed measurement, the stride length calculation would still be within an acceptable error range $( \pm 3.5 \%)$

The natural frequency of a force measurement system has to be sufficiently high so as not to overlap any significant frequency components in the GRF of a foot contact, as the resulting resonance would obscure the forces being measured. The literature agrees that the frequency content of running kinetic measurements is lower than $100 \mathrm{~Hz}$ (Lafortune et al., 1995; Simon et al., 1981; Shorten and Winslow, 1992), therefore a frequency response of greater than $100 \mathrm{~Hz}$ was specified for the equipment.

The overall dimensions of equipment for running are not specified in the literature; however an estimation of the equipment length and width was suggested assuming absolute minimal working values that should not influence unduly standing, walking or running. The minimum length required for running "on the spot" was considered to be at least one step ( $1 / 2$ stride), which gives a minimum length of approximately $1,200 \mathrm{~mm}$. The minimum width was based on the walking base presented in a review of clinical sessions (Gola, 1980), which is $400 \mathrm{~mm}$, although for running this base may be reduced.

Other requirements for the device included: it must operate at fixed and continually variable speeds, which must be displayed to the researcher for monitoring, and in case of power failure the device must have a safe deceleration as well as an emergency stop device, accessible by the researcher and the subject. Additionally, the collected data should be suitable for processing and be graphically displayed to the researcher.

\section{Equipment design}

A standard motorized treadmill was modified to achieve the required performance for specific analyses of amputee running. The whole system was divided into three subsystems: measuring-system/treadmill-bed; driving-system; main support frame.

The treadmill bed should simulate a flat running surface and be able to measure the GRF without interfering in the running process itself. In order to achieve that, the idea of a force platform system being placed under the belt of a treadmill was considered. Essentially consisting of a flat, rigid, rectangular upper plate on which the foot rests, this plate is supported by a base-frame with interposed force transducers capable of detecting the exchanged loads (Hynd et al., 2000).

The GRF range for the three orthogonal directions for running conditions has been outlined previously, as a result of that the measuring range was specified as $3.0 \mathrm{kN}$ (vertically) and $\pm 0.5 \mathrm{kN}$ (laterally). Although the measurements were to be conducted with subjects wearing sports shoes, the overload protection range was specified in order to accommodate for barefoot running, which typically produces greater loads, giving overload ranges of $3.6 \mathrm{kN}$ vertically and $\pm 0.6 \mathrm{kN}$ laterally. 
The force measuring system selected combined four main components: top plate, force transducers, instrumentation and support frame. From a design standpoint it is necessary that the top plate be as light as possible and that its supporting elements be as stiff as possible. This ensures that the natural frequency of the plate is sufficiently high, and that the data from the transducers follow as closely as possible the pattern of the load (Gola, 1980). Taking into account the materials available in the market and the usable space within the treadmill frame, the treadmill bed resulted in a platform length of $1.22 \mathrm{~m}$ by $0.50 \mathrm{~m}$ wide. A guideline working limit for the depth of the force measuring system was set at $280 \mathrm{~mm}$; which represented the maximum height to which the treadmill frame surrounding the force measuring system had available. To satisfy the requirements mentioned above an aluminium honeycomb panel (top plate) and a universal beam joined with cross-bars frame (supporting element) were used (see Figure 1).

Finite Element Analysis (FEA) was used to calculate the resonant frequency of the system, and also allowed the deflection under load and buckling of the force platform structures to be evaluated. FEA was used to refine the frequency response of the structure and to optimise the location of the load cells so as to obtain the largest practicable measuring area. Three different elements were used for the FEA in ANSYS: eight-node 3D structural solid element (load cells); four-node shell element (universal beams and aluminium plate); and two-node 3D elastic beam element (cross-bars).

The measuring force range for the transducers was identical to the one specified for the force platform, allowing for the possibility of a subject stepping directly on top of one transducer. The octagonal load cells were designed using FEA to define the overall height, thickness, central hole diameter and material (Bagesteiro and Tamagna, 1998). The material properties for the aluminium honeycomb, stainless steel and steel used in the FEA analysis are given in Table 1.

A maximum deflection of $0.53 \mathrm{~mm}$ and a maximum equivalent stress (Von Mises - N/mm²) of 140 at the centre of the force platform were calculated at full load $(3.6 \mathrm{kN})$, deemed to be adequate for the application. A modal analysis predicted a natural frequency of the force platform of $275 \mathrm{~Hz}$. The modes of vibration were found to be vertical vibration and horizontal translation. The predicted total mass of the system was $42 \mathrm{~kg}$ (aluminium panel $=6.7 \mathrm{~kg}$, load cells $=1.3 \mathrm{~kg}$, universal beams $=27 \mathrm{~kg}$, cross bars $=7 \mathrm{~kg}$ ). The final design of the measuring system, with an optimised measuring area $800 \mathrm{~mm}$ long by $400 \mathrm{~mm}$ wide, is shown in Figure 1.

\section{Equipment fabrication}

Once the FEA was finished, the fabrication of the load cells and the measuring system was undertaken. Four strain gauge octagonal load cells were fabricated, straingauged and coated (Bagesteiro and Tamagna, 1998). The load cell mountings were made of aluminium alloy and were designed so as to place the load cells between the aluminium honeycomb plate and the universal beam frame and also to enable easy removal if necessary (e.g. to replace a strain gauge). The load cells were oriented in such a way that applied vertical load is carried by all four load cells, and forces in the horizontal directions produced outputs at each of the oriented load cell pairs (Bagesteiro, 1996; Bagesteiro et al., 1998) (see Figure 1). This assembly was then positioned inside the treadmill main frame.

Strain gauge amplifiers were developed using a linear DC amplifier in a 24-pin DIL package (RS 846171 - low noise, low drift and high common mode rejection) specifically configured for resistive bridge measurement. Eight printed circuit boards (RS 435-692) were used to assemble eight strain gauge amplifiers and associated components. A regulated mains powered supply was used for the instrumentation. The frequency and phase response of each strain gauge amplifier was tested to ensure that they were able to provide acceptable amplification of the transduced signal. The tests showed a $(-3 \mathrm{~dB})$ cut-off frequency of 150 $\pm 7 \mathrm{~Hz}$ and an appropriate linear change of phase with frequency.

With four biaxial load cells specified for the measuring system, a total of eight channels of data had to be acquired. The data acquisition card used (National Instruments Co., model PC-LPM-16/PnP) is a low-cost, low-power analogue input, digital, and timing I/O board for PC. The board offers 16 channels of analogue to digital conversion with 12 bit resolution, with a maximum data acquisition rate of $50 \mathrm{kHz}$.

The driving system consists of a $2 \mathrm{HP}$ variable speed DC electric motor providing continuous selection of velocities over a range from 0 to $4 \mathrm{~m} / \mathrm{s}$. The speed is monitored through a tachometer mounted on the motor drive pulley. In addition, to enable direct measurement of the treadmill speed, an optical sensor was incorporated in the treadmill frame and sixty-four marks of reflective tape ( $5 \mathrm{~mm}$ wide) spaced every $65 \mathrm{~mm}$ were glued to the belt side edge. This procedure provides approximately 12 timing marks per foot contact time at a running speed of $3 \mathrm{~m} / \mathrm{s}$. The output from the optical sensor was connected to an analogue channel of the PC-LPM-16/PnP I/O board described above.

After installation, the measuring system was statically and dynamically tested (see the following 
Table 1. Material properties (Beer and Johnston, 1981).

\begin{tabular}{lccc}
\hline & $\begin{array}{c}\text { Aluminium } \\
\text { honeycomb panel } \\
\text { (Aluminium alloy NS4 H6) }\end{array}$ & $\begin{array}{c}\text { Load } \\
\text { cells } \\
\text { (Stainless steel 304) }\end{array}$ & $\begin{array}{c}\text { Frame - universal beams } \\
\text { and cross bars } \\
\text { (Steel BS EN10 025: FE430A) }\end{array}$ \\
\hline Young's modulus $(\mathrm{E}) \mathrm{N} / \mathrm{m}^{2}$ & $6.90 \cdot 10^{10}$ & $2.10 \cdot 10^{11}$ & $1.90 \cdot 10^{11}$ \\
Density $(\rho) \mathrm{kg} / \mathrm{m}^{3}$ & $2.70 \cdot 10^{3}$ & $7.85 \cdot 10^{3}$ & $7.80 \cdot 10^{3}$ \\
Poisson's coefficient $(v)$ & 0.333 & 0.3 & 0.3 \\
Yield strength $\left(\sigma_{\mathrm{e}}\right) \mathrm{N} / \mathrm{m}^{2}$ & $2.80 \cdot 10^{8}$ & $2.8 \cdot 10^{8}$ & $3.40 \cdot 10^{8}$ \\
\hline
\end{tabular}

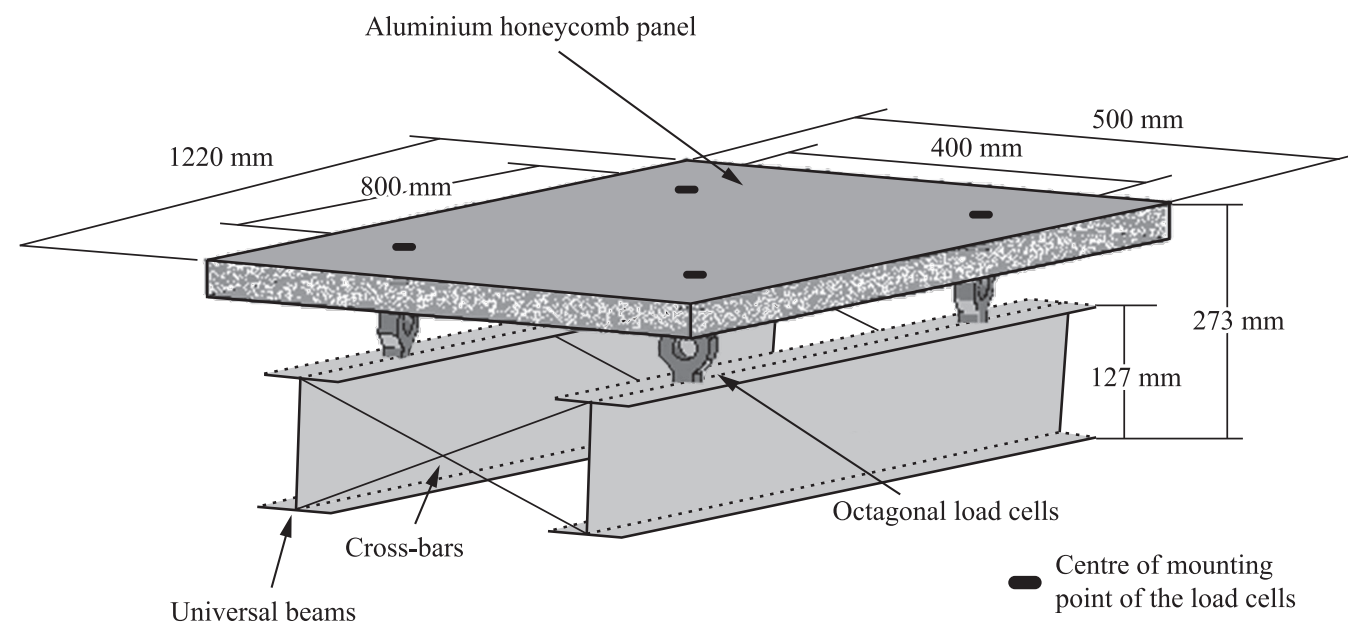

Figure 1. Measuring system components and dimensions.

sub-section). A composite belt (two-ply polyester fabric with high transverse stiffness; topside PVC and bottomside low friction fabric, $\mu=0.2$ ) was placed over the bed and main rollers. In addition, a $1 \mathrm{~mm}$ sheet of PTFE (Poly Tetra Fluor Ethylene) was bonded to the top surface of the aluminium panel using specialised double-sided tape (pressure sensitive tape $-3 \mathrm{M} \mathrm{Scotch}{ }^{\mathrm{TM}}$ ) in order to decrease the friction forces. Finally the motor was placed on the back of the treadmill frame and the electrical connections were made. Once the speed controller was installed the dynamic tests of the treadmill were carried out.

\section{Equipment static and dynamic tests}

Five tests were performed to assess the performance of the instrumented-treadmill: vertical and horizontal force calibration; position of force application; natural frequency; measurement of belt speed variability; vibration and electrical signal variability.

The accuracy of measurement of a vertical static force (magnitude and position) throughout the measurement range of the system was determined by applying discrete known loads of up to $1.5 \mathrm{kN}$ at a symmetrical grid of 21 points on the platform. The results showed a linear response with a maximum error of $\pm 3 \%$ and crosstalk of $\pm 4 \%$ to ML and AP force components. Some hysteresis (up to $8 \mathrm{~N}$ after unloading) was evident.

The position of quasi-dynamic force application could be resolved to within $20 \mathrm{~mm}$ for the ML axis and $40 \mathrm{~mm}$ for the AP axis. The force application position calibration was performed using a 3-point support platform allowing a point load to be applied. Although not required for the prosthetic foot study, quasi-dynamic force calibration tests showed that AP and ML loads could be determined with a maximum error of $\pm 5 \%$, with a maximum crosstalk to the vertical or the orthogonal horizontal component of $\pm 10 \%$. The force calibration tests were repeated three times before the belt was fitted, and repeated once more after it had been positioned. Once the calibration tests were completed, calibration coefficients and corrections routines for the crosstalks were defined. Surfaces equations were used to correct the crosstalk from the vertical direction to the horizontal direction. Correction mapping from the horizontal directions to the vertical direction were considered unnecessary because the maximum crosstalk found was $30 \mathrm{~N}$ at 
full horizontal load $(600 \mathrm{~N})$, which is approximately $0.8 \%$ of the vertical full scale range.

The results from the correction mapping check showed that the error in the measurement of vertical load was force positioning dependent (with a maximum error of $2.3 \%$ at the maximum tested load of $1.5 \mathrm{kN}$ ), but was also found to be linear with load and repeatable. For the horizontal force measurements the verification presented consistent results with a maximum of $7.9 \%$ error for the $y$ direction and $5.4 \%$ for the $x$ direction, however with an acceptable level of error $(< \pm 4.8 \%)$ within the rectangular area covered by the transducer centres. Once more the results were position dependent.

The dynamic response of the system was tested experimentally using a uniaxial accelerometer mounted at various points at the three orthogonal directions on the measuring system and its response to an impulse load. The accelerometer signal was sampled at $1 \mathrm{kHz}$ for four seconds and the frequency content determined using a Direct Fourier Transform. The natural frequencies were $250 \mathrm{~Hz}$ vertically, $350 \mathrm{~Hz}$ and $430 \mathrm{~Hz}$ horizontally. The tests were repeated with an adult standing at the centre of the treadmill bed. These showed a negligible effect $( \pm 2 \mathrm{~Hz})$ on the natural frequency of vibration of the system. The theoretical frequency response was approximately 1.1 greater than the experimentally determined value, which could be attributed to the modelled constraints being too rigid at the joints between different parts of the structure.

The accuracy of directly measuring the loaded and unloaded belt speed along with its consistence was also tested. The results indicated that the unloaded belt speed variation was up to $\pm 2.4 \%$. The belt loaded tests consisted of a person (bodyweight $=650 \mathrm{~N}$ ) walking $(1.4 \mathrm{~m} / \mathrm{s})$ and running $(2.8 \mathrm{~m} / \mathrm{s})$ on the treadmill. The belt speed variations for the loaded tests were up to $\pm 6.0 \%$ and $\pm 7.8 \%$ for walking and running, respectively.

The background vertical 'noise' was $< \pm 12 \mathrm{~N}$ when the motor was turned off and $< \pm 30 \mathrm{~N}$ when turned on (no subject on the treadmill) at speeds up to $3.3 \mathrm{~m} / \mathrm{s}$. A vibration analysis showed a speed dependent, random response component, which can be substantially removed ( $95 \%$ ) by averaging the foot contacts.

Dynamic tests were performed to investigate the potential level-mounting problem together with the frictional forces generated between the top of the platform and the bottom surface of the belt (i.e. additional horizontal forces introduced to the system). This assessment showed some indication of a speed influence on the friction coefficient values and it was speculated that there could be a relationship between friction coefficients, treadmill belt speed and percentage of stance phase. As a result a polynomial best-fit was applied to the data and an equation for the kinetic coefficient of friction was derived. Correction routine was implemented in the treadmill software; however this correction is only applied after the force-averaging algorithm has been processed, once the coefficient of friction was calculated to be relating to stance phase. Although some of the results were encouraging, others were less convincing, suggesting that further investigation is needed in order to get more information about the friction behaviour and be able to validate the method (Bagesteiro, 1999).

\section{Software}

Two software suites written in LabVIEW ${ }^{\circledR}$ (National Instruments) complement the treadmill hardware. The first enables the acquisition, presentation, manipulation and storage of data from the treadmill system. It has a simple graphical level meter, which displays and continuously updates the outputs from each force axis on the force platform. The programme is used primarily to check signal levels and connections prior to a trial session. Data acquisition is conducted at a rate, and for a maximum duration, controlled by the operator. Forces $v s$. time graphs are plotted on-screen along with the speed variation during foot contacts and distance covered by the subject. Data can be stored as well as exported in a text format, to be manipulated later in a spreadsheet programme for different displays of graphs and charts. The developed system enables rapid evaluation of different prosthetic limb settings (e.g artificial knee mechanisms, alignments, and prosthetic feet).

The software automatically corrects the force values according to the data from the calibration of the platform. The three orthogonal components of the GRF and the application point $(\mathrm{CoP})$ coordinates are calculated using the following equations (Bagesteiro, 1999):

$$
\begin{aligned}
& F_{Z}[\mathrm{~N}]=\left(V_{1} \cdot L C_{V 1}\right)+\left(V_{2} \cdot L C_{V 2}\right)+ \\
& +\left(V_{3} \cdot L C_{V 3}\right)+\left(V_{4} \cdot L C_{V 4}\right) \\
& F_{Y}[\mathrm{~N}]=\left[\left(H_{2} \cdot L C_{H^{2}}\right)-\left(H_{4} \cdot L C_{H 4}\right)\right]-\left(F_{Z} \cdot y_{c o e f}\right) \\
& F_{X}[\mathrm{~N}]=\left[\left(H_{3} \cdot L C_{H 3}\right)-\left(H_{1} \cdot L C_{H 1}\right)\right]-\left(F_{Z} \cdot x_{c o e f}\right) \\
& X[\mathrm{~m}]=0.05+\frac{\left\{\left[\left(V_{2} \cdot L C_{V 2}\right)+\left(V_{3} \cdot L C_{V 3}\right)\right] \cdot 0.40\right\}}{F_{Z}} \\
& Y[\mathrm{~m}]=0.21+\frac{\left\{\left[\left(V_{4} \cdot L C_{V 4}\right)+\left(V_{3} \cdot L C_{V 3}\right)\right] \cdot 0.80\right\}}{F_{Z}}
\end{aligned}
$$


where $F_{Z}[\mathrm{~N}]$ is the force in the $z$ direction (vertical); $F_{Y}[\mathrm{~N}]$ is the force in the $y$ direction (antero-posterior $-\mathrm{AP}$ ); $F_{X}[\mathrm{~N}]$ is the force in the $x$ direction (mediolateral - ML); $V_{i}[\mathrm{~V}]$ is the vertical voltage output from the load cell; $H_{i}[\mathrm{~V}]$ is the horizontal voltage output from the load cell; $L C_{V i}$ is the load cell calibration coefficient in the vertical direction; $L C_{H i}$ is the load cell calibration coefficient in the horizontal direction; $X[\mathrm{~m}]$ is the force position at $x$ direction (ML); $Y[\mathrm{~m}]$ is the force position at $y$ direction (AP); $y_{\text {coef }}$ is the crosstalk coefficient for the $y$ direction; $x_{\text {coef. }}$ is the crosstalk coefficient for the $x$ direction.

The second application enables separation of the foot contacts in left and right feet as well as averaging the multiple foot contacts. This programme implements a cubic spline function using built-in routines from LabVIEW $^{\circledR}$, resulting in averaged ground reaction force curves as a function of the percentage of stance phase. Additionally, a set of gait parameters (including stride time, stride length, average stance phase for each foot and running speed) are derived.

\section{Results and Discussion}

A pilot study was undertaken to evaluate the developed system. Gait parameters during running from three volunteers were measured (one non-amputee and two unilateral amputees (trans-tibial (BK) and transfemoral (AK)). An explanation of the experiment was given to the participants and informed consent taken in accordance with guidelines for investigations with human subjects. Three symmetry variables (defined elsewhere (Robinson et al., 1987)) were used to quantify differences between left and right limbs from the treadmill data: first vertical force peak; second vertical force peak and stance time (symmetry index $=\%$ between left and right limbs data). The stride time, stride length, average speed and average vertical force were also calculated.

Each subject was familiarised with the experimental procedure and then asked to stand still in the middle of the treadmill load measuring area, while data for the body weight measurement was collected. This was followed by a few minutes of walking to acclimatise to the treadmill. After that a three-minute period of comfortable jogging was given for habituation to the treadmill running trial. The speed was then increased to give three minutes of running at a comfortable speed. Eight seconds of data, representing 10 to 12 consecutive complete strides of running (i.e. at least 10 foot contacts per foot) were collected for each running trial. Data acquisition took place after approximately 2 minutes of running at the two preselected speeds. The treadmill inclination was always $0^{\circ}$. A video system was used to record the sagittal and coronal view of the subject's feet during data acquisition. The subjects were attired in comfortable running shoes, shorts and T-shirt.

Figures 2 and 3 illustrate averaged (splined) VGRF for 12 consecutive complete strides, from a non-amputee and a BK amputee when running on the treadmill at different speeds. The BK amputee data represents two different conditions of the prosthetic limb with and without spring in the TeleTorsion device. Table 2 shows the spatio-temporal parameters calculated for all subjects.

The symmetry index data for the normal subjects running at $10 \mathrm{~km} / \mathrm{h}(2.78 \mathrm{~m} / \mathrm{s})$ were less than $7 \%$,

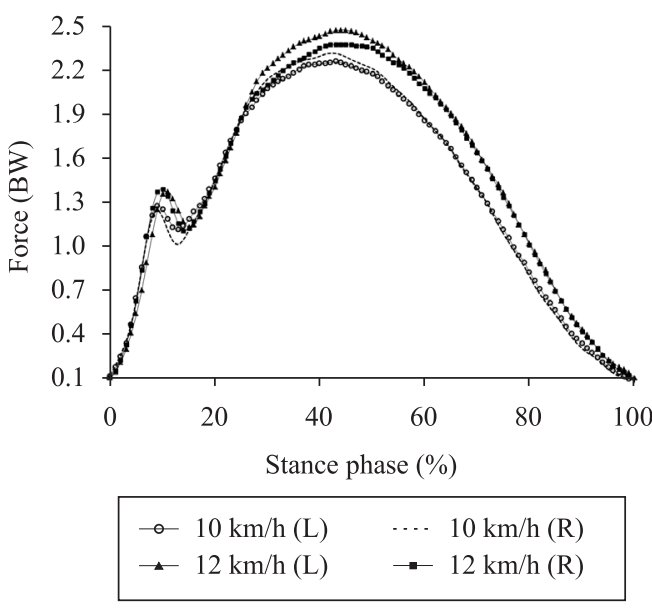

Figure 2. Average (12 consecutive complete strides - splined) VGRF of a non-amputee running at the two preset speeds $(10$ and $12 \mathrm{~km} / \mathrm{h}$ ) $(\mathrm{L}=$ left limb; $\mathrm{R}=$ right limb; $\mathrm{BW}=$ body weight $)$

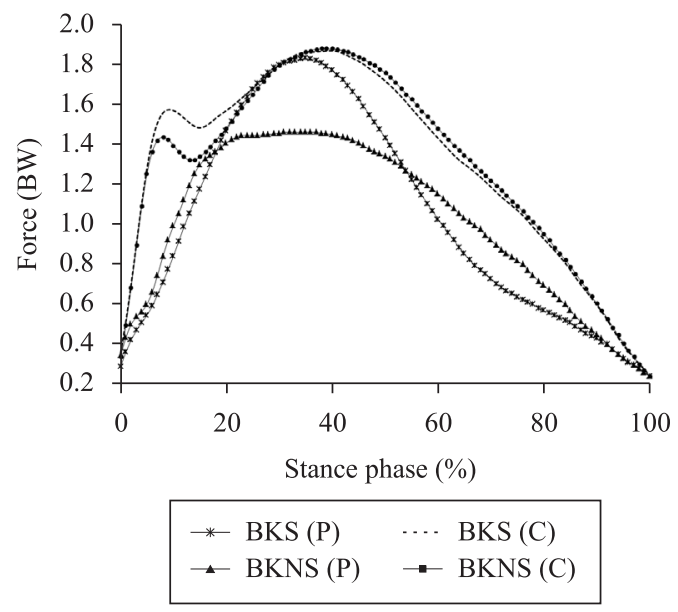

Figure 3. Average (12 consecutive complete strides - splined) VGRF of a trans-tibial amputee running with the spring on the prosthetic limb (BKS) and without the spring (BKNS) running at comfortable speed $(\mathrm{P}=$ prosthetic limb; $\mathrm{C}=$ contralateral limb; $\mathrm{BW}=$ body weight $)$. 
Table 2. Subjects' spatio-temporal parameters for the two preset running speeds $10 \mathrm{~km} / \mathrm{h}(2.78 \mathrm{~m} / \mathrm{s})$ and $12 \mathrm{~km} / \mathrm{h}(3.33 \mathrm{~m} / \mathrm{s})$.

\begin{tabular}{|c|c|c|c|c|c|c|}
\hline \multirow{2}{*}{$\begin{array}{c}\text { Running speed } \\
{[\mathrm{km} / \mathrm{h}]}\end{array}$} & \multicolumn{2}{|c|}{ Non amputee } & \multicolumn{2}{|c|}{ Trans-tibial (BK) } & \multicolumn{2}{|c|}{ Trans-femoral (AK) } \\
\hline & 10 & 12 & 10 & 12 & 10 & 12 \\
\hline Stride time $[\mathrm{s}]$ & 0.75 & 0.70 & 0.70 & 0.65 & 0.80 & 0.75 \\
\hline Stride length [m] & 2.00 & 2.30 & 1.40 & 1.60 & 1.55 & 1.70 \\
\hline Average speed $[\mathrm{m} / \mathrm{s}]$ & 2.70 & 3.20 & 2.30 & 2.60 & 1.75 & 2.00 \\
\hline
\end{tabular}

which compare well with OVGR running presented in the previous work (Giakas and Baltzopoulos, 1997). Asymmetry values of up to $24 \%$ were found for the BK trial $(9 \mathrm{~km} / \mathrm{h}=2.5 \mathrm{~m} / \mathrm{s})$. The AK trial showed that for the prosthetic limb, there was a more rapid decrease in the push off force, occurring between 50 and $60 \%$ of the stance phase, whereas the impacts peak within $15 \%$.

During the pilot study it was recognised that heavy subjects (i.e. bodyweight $\geq 950 \mathrm{~N}$ ) would not be able to walk or run comfortably on the treadmill. The loading conditions increased considerably the friction applied to the treadmill belt at foot contact, causing a significant change in the treadmill speed, therefore creating difficulties for running, and resulting in the volunteer having to distribute of the load between the handrail bars and the treadmill bed.

\section{Conclusion}

The instrumented treadmill has been used for the measurement of kinetic and temporal-spatial running data, for both non-amputee and amputee subjects. Preliminary results are positive, suggesting that the instrumented treadmill is appropriate for the measurement of the running gait of adult subjects and in particular for prosthetic limb optimisation. However, further work is required before the treadmill can be used routinely. Key areas of investigation are hardware and software enhancements, e.g. suitability for heavy subjects and decrease in data processing time, and comparative studies of treadmill and OVGR running for amputees.

In addition, it would be useful to have a "normal" database, for a range of ages and running speeds, with which to compare the amputee running data acquired during research assessments. The database could be included with the instrumented treadmill software for immediate recall and comparison with the data on screen. A more extensive study of the horizontal forces is necessary so that appropriate correction algorithms can be fully implemented in the software.

\section{Acknowledgements}

The authors gratefully acknowledge the financial support from CNPq/Brazil, and S.C. Hughes for helpful discussion during this research.

\section{References}

BAGESTEIRO, L. B. Desenvolvimento de uma plataforma para a análise das forças produzidas por pessoas. 1996. 112 f. Dissertação (Mestrado em Engenharia Mecânica)Escola de Engenharia, Universidade Federal do Rio Grande do Sul, Porto Alegre, 1996.

BAGESTEIRO, L. B. Development of a ground reaction force-measuring treadmill for the analysis of prosthetic limbs during amputee running. 1999. $245 \mathrm{f}$. Thesis $(\mathrm{PhD}$ Biomedical Engineering)-School of Mechanical and Materials Engineering, University of Surrey, Guildford, 1999.

BAGESTEIRO, L. B.; LARANJA, R. A. C.; TAMAGNA, A. The development of a force platform: numerical and experimental analysis. American Society of Mechanical Engineers, Bioengineering Division, BED-v. 39, Advances in Bioengineering, p. 325-329, 1998.

BAGESTEIRO, L. B.; TAMAGNA, A. Two direction force measurement transducers. In: Haake, S. J. (Ed.) The Engineering of Sport. Cambridge: Blackwell Science, 1998. p. 235-241.

BATES, B. T.; OSTERNIG, L. R.; SAWHILL, J. A.; JAMES, S. L. An assessment of subject variability, subject-shoe interaction, and the evaluation of running shoes using ground reaction force data. Journal of Biomechanics, v. 16, n. 3, p. 181-191, 1983. http://dx.doi.org/10.1016/0021-9290(83)90125-2

BEER, F. P.; JOHNSTON, E. R. Mechanics of Materials. New York: McGraw-Hill, 1981. 616 p.

BELLI, A.; BUI, P.; BERGER, A.; LACOUR, J. R. A treadmill for measurement of ground reaction forces during walking. In: CONGRESS OF THE INTERNATIONAL SOCIETY OF BIOMECHANICS, 15., 1995, Jyvaskyla, Finland. Proceedings... Jyvaskyla, 1995. p. 100.

CAVANAGH, P. R. Biomechanics of distance running. Champaign: Human Kinetics, 1990. 362 p.

DAVIS, B. L.; CAVANAGH, P. R. Decomposition of superimposed ground reaction forces into left and right force profiles. Journal of Biomechanics, v. 26, n. 4-5, p. 593-597, 1993. http://dx.doi.org/10.1016/0021-9290(93)90020-F

DINGWELL, J. B.; DAVIS, B. L. A rehabilitation treadmill with software for providing real-time gait analysis and visual feedback. Journal of Biomechanical Engineering, v. 118 , n. 2, p. 253-255, 1996. PMid:8738792. http://dx.doi. org/10.1115/1.2795968 
DINGWELL, J. B.; DAVIS, B. L.; FRAZIER, D. M.; CAMPBELL, J. H. Real-Time Symmetry Assessment and Feedback in Amputee Rehabilitation. In: BIENNIAL CONFERENCE OF THE CANADIAN SOCIETY FOR BIOMECHANICS, 8 ., 1994, Calgary. Proceedings... Calgary: Société Canadienne de Biomécanique (SCB), University of Calgary. p. 48-49.

ENOKA, R. M.; MILLER, D. I.; BURGESS, E. M. Below-knee amputee running gait. American Journal of Physical Medicine, v. 61, n. 2, p. 66-84, 1982.

FEWSTER, J. B. SMITH, G. A. Development of a treadmill for measuring vertical ground reaction forces and center of pressure during gait. In: CONGRESS OF THE INTERNATIONAL SOCIETY OF BIOMECHANICS, 15., 1995, Jyvaskyla, Finland. Proceedings... Jyvaskyla, Finland, 1995. p. 274.

FUGLEWICZ, D.; KLAVOON, W. A ground reaction force measuring treadmill. In: ANNUAL MEETING OF THE AMERICAN SOCIETY OF BIOMECHANICS, 18., 1994, Columbus, Ohio. Proceedings... Columbus: Ohio State University, 1994. p. 324.

GIAKAS, G.; BALTZOPOULOS, V. Time and frequency domain analysis of ground reaction forces during walking: an investigation of variability and symmetry. Gait and Posture, v. 5, n. 3, p. 189-197, 1997. http://dx.doi.org/10.1016/ S0966-6362(96)01083-1

GOLA, M. M. Mechanical design, constructional details and calibration of a new force plate. Journal of Biomechanics, v. 13, n. 2, p. 113-128, 1980. http://dx.doi.org/10.1016/00219290(80)90185-2

HYND, D.; HUGHES, S. C.; EWINS, D. J. The development of a long, dual-platform triaxial walkway for the measurement of forces and temporal-spatial data in the clinical assessment of gait. Proceedings of the Institution of Mechanical Engineers, Part H: Journal of engineering in medicine, v. 214, n. 2, p. 193-201, 2000. http://dx.doi. org/10.1243/0954411001535354

JOHNSON, L. W.; CALDER, C. A.; SMITH, G. A. Instrumenting an exercise treadmill for evaluation of vertical ground reaction forces. In: SEM SPRING CONFERENCE, 1993, Dearborn. Proceedings... Dearborn, 1993. 988 p.

KEGEL, B.; WEBSTER, J. C.; BURGESS, E. M. Recreational activities of lower extremity amputees: a survey. Archives of Physical Medicine and Rehabilitation, v. 61, n. 6, p. 258-264, 1980.

KOBYLARZ, R. Overground vs. Treadmill Running. Sport Health, v. 8, n. 2, p. 33-34, 1990.

KRAM, R.; POWELL, A. J. A treadmill-mounted force platform. Journal of Applied Physiology, v. 67, n. 4, p. 1692-1698, 1989.

LAFORTUNE, M. A.; LAKE, M. J.; HENNIG, E. M. Transfer function between tibial acceleration and ground reaction force. Journal of Biomechanics, v. 28, n. 1, p. 113-117, 1995. http://dx.doi.org/10.1016/0021-9290(95)80014-X
MAINKA, C.; BOENICK, U. Integrated gait analysis for future routine clinical use. Biomedizinische Technik, v. 38 , n. 12 , p. $325-331$, 1993. http://dx.doi.org/10.1515/ bmte.1993.38.12.325

MARTIN, M. A.; GAGNON, M.; PIERRYNOWSKI, M. R. Ground reaction forces and frontal plane hip, knee and ankle angles during running on a treadmill. In: de GROOT, G., HOLLANDER, A. P.; HUIJING, P. A.; van INGEN SCHENAU, G. J. (Eds.) Biomechanics XI-B. Amsterdam: Free University Press, 1987. p. 645-649. (International Series on Biomechanics).

MICHAEL, J. W.; GAILEY, R. S.; BOWKER, J. H. New developments in recreational prostheses and adaptive devices for the amputee. Clinical Orthopaedics and Related Research, v. 256, p. 64-75, 1990.

NIGG, B. M.; COLE, G. K.; BRUGGEMANN, G.-P. Impact forces during heel-toe running. Journal of Applied Biomechanics, v. 11, n. 4, p. 407-432, 1995.

OHMICHI, H. Application of a treadmill/force plate system to the kinematics of pathological gait. 1991. $453 \mathrm{f}$. Thesis (PhD)-University of Western Australia Perth, 1991.

PANDIAN, G.; KOWALSKE, K. Daily functioning of patients with an amputated lower extremity. Clinical Orthopaedics and Related Research, v. 361, p. 91-97, 1999. http://dx.doi. org/10.1097/00003086-199904000-00013

ROBINSON, R. O.; HERZOG, W.; NIGG, B. M. Use of force platform variables to quantify the effects of chiropractic manipulation on gait symmetry. Journal of Manipulative and Physiological Therapeutics, v. 10, n. 4, p. 172-176, 1987.

SCHNEIDER, K.; HART, T.; ZERNICKE, R. F.; SETOGUCHI, Y.; OPPENHEIM, W. Dynamics of below-knee child amputee gait: SACH foot versus Flex foot. Journal of Biomechanics, v. 26, n. 10, p. 1191-1204, 1993. http://dx.doi.org/10.1016/0021-9290(93)90067-O

SHORTEN, M. R; WINSLOW, D. S. Spectral analysis of impact shock during running. Journal of Applied Biomechanics, v. 8, n. 4, p. 288-304, 1992.

SIMON, S. R.; PAUL, I. L.; MANSOUR, J.; MUNRO, M.; ABERNETHY, P. J.; RADIN, E. L. Peak dynamic force in human gait. Journal of Biomechanics, v. 14, n. 12, p. 817-822, 1981. http://dx.doi.org/10.1016/0021-9290(81)90009-9

Van INGEN SCHENAU, G. J. Some fundamental aspects of the biomechanics of overground versus treadmill locomotion. Medicine and Science in Sports and Exercise, v. 12, n. 4, p. $257-261,1980$. http://dx.doi.org/10.1249/00005768 198024000-00005

WARD, K. H.; MEYERS, M. C. Exercise performance of lowerextremity amputees. Sports Medicine, v. 20, n. 4, p. 207-214, 1995. PMid:8584846. http://dx.doi.org/10.2165/00007256199520040-00001

WINTER, D. A.; SIENKO, S. E. Biomechanics of below-knee amputee gait. Journal of Biomechanics, v. 21, n. 5, p. 361-367, 1988. http://dx.doi.org/10.1016/0021-9290(88)90142-X

\section{Autores}

\section{Léia Bernardi Bagesteiro}

Centro de Engenharia, Modelagem e Ciências Sociais Aplicadas - CECS / UFABC, Av. dos Estados, 5001, CEP 09210-580, Santo André, SP, Brazil

David Gould, David John Ewins

Centre for Biomedical Engineering, Faculty of Engineering and Physical Sciences,

University of Surrey - United Kingdom 